\title{
The Domestication of Law and Literature
}

J. M. Balkin

Richard Posner, Law and Literature: A Misunderstood Relation. Cambridge: Harvard University Press, 1988. Pp. xi +371 . $\$ 25.00$.

\section{BEFORE THE ESSAY:}

\section{A DECONSTRUCTIVE PRELUDE}

How should a deconstructionist go about reviewing Judge Richard Posner's new book, Law and Literature: A Misunderstood Relation? As Judge Posner tells us, deconstructionists "take an ostensibly serious prose passage and immediately get hung up on the first word, which may be an unintended pun or a homonym or a false cognate or may contain a subordinate meaning . . . at war with the surface meaning" (at 213). Indeed, deconstructionists do much worse things. They deliberately look for the marginal, the obscure, the disregarded in texts (and in thought), believing that this will shed light on the problems of a text, its blindnesses, or its ideological presuppositions.

We could begin our deconstruction, then, by focusing on an especially marginal element of this book-the dust jacket. On the dust jacket one finds a very pleasant picture of Judge Posner smiling, which is in marked contrast to the photograph on the dust cover of his last book, The Economic Structure of Tort Law, in which he appeared to be frowning. Surely, we might think, the move from economics to literature has improved his spirits considerably. Perhaps this signifies the dismal seriousness of economics as opposed to the carefree nonseriousness of literature. Perhaps it mirrors the profound and difficult thoughts that weigh upon

J. M. Balkin is professor of law and Graves, Dougherty, Hearon \& Moody Centennial Faculty Fellow, University of Texas. J.D. 1981, Harvard University. The author wishes to thank Sandy Levinson and Howard Erlanger for their comments on previous drafts of this review essay. 
our minds when we mathematically model the Coase Theorem, as opposed to the joyful uplifting of our spirits that naturally occurs during our lighthearted ramblings through Wordsworth, Coleridge, and Yeats. Yet if, as semiotics tells us, meaning is constructed in a system of differences, perhaps the dust jacket is slyly signifying that the difference between law and economics and law and literature is the difference between Judge Posner serious and Judge Posner smiling, between the really rigorous thinking that economics demands and the sort of daydreaming we do in an overstuffed chair with a novel in one hand and a glass of brandy in the other. Perhaps this is really so, or perhaps this is just an element in a belief system that conveniently supports other conclusions the author would have us accept. Perhaps this attitude affects (or infects) everything that Judge Posner has to say about the subject of law and literature. Perhaps.

Yet, if we are to search through this book for the most meaningless, insignificant item that we could wrench out of context, we should not be content to stop with the dust jacket. After all, this would not sufficiently display the profound disrespect for serious academic and scholarly values that one normally associates with deconstruction. We should not be permitted to cease until we have found the most unimportant, unintended allusion in the entire text that is Law and Literature: A Misunderstood Relation, an allusion that could not possibly have the meaning the author intended it to have. And not only must this be an unintended meaning, it should be placed on a page with no number, lost in the first few pieces of paper that one leafs through hurriedly on the way to the real beginning of the work. There, on the dedication page, we find these fascinating words:

For my Mother, who initiated me into the pleasures of literature, and my Father, who encouraged me to go to law school.

If meaning is inscribed in a system of differences, what a wealth of differences is buried in this innocent passage. The Mother, the feminine, who initiated the young Dick Posner (as one might be initiated into mysteries by a priestess of the ancient world) into pleasure (literature). The Father, the masculine, who encourages young Dick Posner (be firm and steadfast!) to go (travel, journey) to law school (an arduous endeavor, surely).

Moreover, if we abstract away the intended meaning of this text, the biographical references, the actual Mother and Father fondly recognized and remembered by a dutiful son, we are left with a curious division of the interdisciplinary world into Father and Mother, masculine and feminine, work and pleasure, reason and emotion, public (journey to a school of law) and private (initiation into mysteries), serious and nonserious, law and literature. 
Indeed, in this interdisciplinary volume we witness two disciplines and two ways of disciplining. But the discipline of the Father is different from the discipline of the Mother, and each has its own place in the disciplining of a child (or of a civilization). For by civilization do we not mean acculturation into social values, which is the very purpose of discipline?). The Father's place is in the public world of work, power, and social order; the Mother's place in the private world of home, entertainment, and child rearing. Each should know its position in the order of things, for to mix these disciplines, to erase these boundaries, is a threat to discipline (read here authority) itself.

Suppose we were to think abstractly, but in Freudian terms, about this system of difference. There is the Oedipal attraction to the Mother (literature, play, entertainment, pleasure) that is sought after and forbidden, forsaken for fear of castration by the Father (law, authority, power, politics). The Oedipal conflict is resolved only by the male child's identification with the Father and his values, and a corresponding sublimation and subordination of the values of the Mother. Only through such wrenching emotional efforts is civilization achieved. And what could be more threatening to a child than watching the Mother and Father engaged in coitus, conjoined in an undifferentiated union of power and pleasure, of law and literature? Perhaps we know, in our heart of hearts, what Father and Mother do in private. But to make this union of reason and emotion public-to display it for all the world to see-would this not pose the greatest possible threat to our sense of stability, to the compromise, sublimation, and subjugation that has made our civilization possible?

Law and literature, then, must remain separate, each in its own sphere. We must emphasize their differences as much as their similarities. And to the extent that we allow literature into the legal academy, allow Mother into the public realm of politics and power, we must do so in a way that does not threaten these essential divisions. Mother must be entertaining, interesting, but ineffectual. She can tell us nothing about the real issues of politics and power, law and authority. She is at her best when she decorates our offices, but does not tell us how to run them.

I could end the review here, confident that from the margins of this book I had drawn out the ideology infused in its pages. Yet although I believe that this depiction is ultimately correct, it would not do justice to what is, after all, an elegant and scholarly piece of work-a work which, while insisting that literature should be entertaining, endeavors (successfully) to be so itself, while being deadly serious in its aims. If I ended the review here, in this reconstructive reverie, many readers might think that I was being insufficiently serious. Therefore it is important to go forward, and to explain in detail what could just as easily be summed up in a photograph on a dust jacket, or an epigram on a dedication page. 


\section{INTRODUCTION: THE IDEOLOGICAL SIGNIFICANCE OF LAW AND LITERATURE}

I do not like the idea of letting politics shape my cultural life.

-Richard Posner (at 301)

There is the story of the psychiatrist who gave a new patient a Rorschach test. He held up the first inkblot and asked, "Mr. Smith, what do you see in this picture?"

"That's easy," the patient responded. "That's a picture of two people making love."

"And what about this one?" the doctor asked, revealing another inkblot.

"Same thing. Two people having sex."

"And this one?" the doctor asked, producing yet a third example.

"Same thing. They're having intercourse in this one too."

"Mr. Smith," the psychiatrist responded gravely. "I'm afraid you have an unhealthy fixation with sex."

"What do you mean?" said Smith indignantly. "You're the one showing the dirty pictures."

Readers of Law and Literature: A Misunderstood Relation may easily find themselves in a position much like that of Mr. Smith. For despite Judge Posner's disclaimers to the contrary, despite his view that "[t]he literary should be a sphere apart" from political and moralistic concerns (at 302), indeed, despite the many amiable and enjoyable discussions of literary works within the chapters of this book, we may perhaps be forgiven if everywhere within its pages we will find evidence of an intensely political and ideological debate-a debate about the future direction of the law and literature movement in particular and legal scholarship in general. Perhaps a reader who finds these things in the text is, like Mr. Smith, simply the victim of a fixation with politics that is an unavoidable symptom of the age we live in. But perhaps Judge Posner's Law and Literature is ideologically slanted without knowing it, a polemic unconsciously offered with the best of intentions. Perhaps Judge Posner has been showing us political pictures all along.

Posner himself reminds us at the beginning of the book that the event which awoke him from his dogmatic slumbers and made him attend to the question of law and literature was Robin West's attack on his economic theories. ${ }^{1}$ As long as law and literature kept in its appointed place-as a

1. At iv. See R. West, "Authority, Autonomy, and Choice: The Role of Consent in the Moral and Political Visions of Franz Kafka and Richard Posner," 99 Harv. L. Rev. 384 (1985); West, "Submission, Choice, and Ethics: A Rejoinder to Judge Posner," 99 Harv. L. Rev. 1449 (1986). 
harmless diversion for lawyers who enjoyed reading great novels-it was an entertaining but irrelevant academic movement of no immediate concern. But the moment that legal literati began to suggest that the study of literature revealed the moral bankruptcy of law and economics, or attempted to remove law and economics from its preeminent position in interdisciplinary studies, Judge Posner sprang eagerly to the defense.

Of course, the fact that Posner sees much of the current law and literature movement as intersecting with the critical legal studies movement (at 177-78) made the subject doubly interesting, for Judge Posner is no great friend of the latter movement. Indeed, I suspect that, notwithstanding the distinguished work of such law and literature scholars as James Boyd White, many legal academics view "law and literature" as a code word for CLS; they wish that this new generation of "lit-crits" would simply own up to what they are doing under the more innocent and unprepossessing banner of literary theory.

Thus, the fact that a scholar of such importance and with such political views as Judge Posner is writing a book on law and literature at this moment in the history of the legal academy is no mere coincidence. It is part of a larger dispute over the terms and conditions of legal scholarship in an increasingly interdisciplinary era in which law and economics has established itself as a prominent (and often politically conservative) force. Although this book is nominally about law and literature, and although it brings together many disparate essays that often appear unrelated, the problem of the status of law and economics in the legal academy hovers around its pages worrisomely. It is this recurring theme, in fact, which makes the book so fascinating, and informs its most important arguments.

As an example of this, I must jump ahead to a crucial passage in the book's sixth chapter. After offering advice about how judges can improve their opinions by studying examples of rhetoric in great works of literature, but not by paying attention to these works' moral or political content, Posner suddenly shifts to a seemingly unrelated subject:

In emphasizing the importance of . . a an awareness of the ... complexity of the human condition and of perspectives other than the writer's own, I may seem to be arming the critics of the application of economics to law.... Peter Teachout, in an admiring review of James Boyd White's book When Words Lose Their Meaning, argues that the language of economics, in its coldness, colorlessness, and striving for scientific precision, distorts human reality and sMothers alternative perspectives (at 309-10).

Here Posner launches into a passionate defense of economic science. He argues that 
it is a fallacy to think that a mode of analysis that does not wear its emotions on its sleeve is therefore callous.

In supposing that the language of economics is a kind of Newspeak, Teachout reveals a misunderstanding of the nature of a scientific vocabulary, such as that of economics. The aim of such a vocabulary is not to conceal unpleasant realities but to achieve analytical precision. ... The bureaucratic impersonality of legal prose ... may give an impression of precision to the unschooled, but the real purpose is to obfuscate and euphemize, a goal foreign to economic and other scientific discourse.

There is irony in denouncing the economic vocabulary as a flight from reality, when the economic approach to human behavior insists on just the sort of gritty realism that the New Criticism taxed some Romantic Poetry with trying to evade. In its insistence on the centrality of self-interest (and hence of incentives) in motivating human action, in its insistence that everything has a cost--that there is no such thing as a free lunch-and in its consequent skepticism about Utopian projects, economics is revealed as a bastion of Enlightenment values. The absence of Romantic uplift is precisely what makes economics-the rejection of Romanticism in the sphere of governmentso repugnant to the heirs of Romanticism (at 311-12, footnotes omitted).

In this passage we witness the governing oppositions that motivate the entire book: reason opposed to emotion, Enlightenment values opposed to woolly-headed sentimentalism, economics opposed to romanticism, science opposed to superstition, hard-headed realism opposed to utopian dreaming. These echo other oppositions mentioned in earlier chapters-maturity and realism opposed to childishness and rebelliousness, restraint opposed to radicalism, order opposed to anarchy, respect for the importance of authority opposed to reckless disobedience, the Apollonian vision versus the Dionysian. ${ }^{2}$ What is important here is not whether these oppositions accurately describe reality-whether economics really reflects Enlightenment values more than literature does, for example-but the meaning that these oppositions have for Judge Posner and the way in which he constructs the world.

So clearly does this passage reveal Posner's world view that it is not

2. At $137-38,140-46,149-50,152-55,203-04,216$ n.6, 249, 252, 312 n.74. Posner's reference to the "Apollonian" and "Dionysian" recalls Nietzsche's distinction between two complementary principles of artistic expression. Apollo represented order, restraint, form, individuation, and repose, while Dionysus represented energy without boundaries, powerful emotional experience, including both ecstasy and terror, and abandonment of the self to the greater unity of the life force. Nietzsche saw both elements as equally necessary to human existence. See F. Nietzsche, "The Birth of Tragedy from the Spirit of Music," reprinted in The Basic Writings of Nietzsche (W. Kaufmann, trans. 1968). 
difficult to see the connection between the above oppositions and the one that is nominally the subject of the book-the opposition between law and literature. As Posner himself exclaims at one point, "[i]s not the judicial process quintessentially Apollonian?"3 For example, when discussing the differences between legal and literary interpretation, Posner emphasizes that legal interpretation requires restraint, order, and respect for authority, because so much in real life depends upon such interpretation, while literary interpretation is able to emphasize freedom and novelty because it is mere entertainment upon which nothing substantial turns (at 243-44, 249-52).

Nevertheless, these related oppositions (which we may for convenience abbreviate as a single great opposition between reason and passion) are not merely differences between selected concepts-they are also privilegings of particular concepts. All things being equal, Posner's writing clearly displays a preference for the first term in each opposition over the second one. This preference is recapitulated when Posner considers the appropriate function of the devalued term in each opposition. Reason is better than passion, but passion has its proper place: Passion is at its best when it is most like reason. Thus, if literature is to law as passion is to reason, the best literature is that which most captures or reflects those things associated with reason. Posner thus explains that he prefers literature which reflects a mature, realistic attitude towards life (at 306). Similarly, in his definitional hierarchy, style is opposed to logic or reasoning (at 270-73). Yet the best style is that which Posner sees as possessing the right "literary craft values," that is, the values of reason-impartiality, scrupulousness, sobriety, restraint, and avoidance of hyperbole (at 305-7).

Indeed, even Romanticism has value in its proper place: "I hasten to add," Posner says at one point, "that it would be equally one-sided to disregard the Romantic impulse-that sense of infinite human potential that is not only a permanent part of human nature but a source historically of much good as well as ill" (at 307). But the proper place of Romanticism is as a servant to the forces of reason-its raison d'etre must be raison, as Posner makes clear: "[h]ad it not been for the 'aspiring minds' [i.e., the romantic impulse] . . . there might have been no Renaissance, no scientific revolution, no Enlightenment-maybe little progress on any front" (at 307). Even when Posner celebrates passion, he does so in the name of reason.

Yet the construction of the world in terms of reason versus passion is not simply a preference for reason and those things that are associated with reason; it is also a means of concealing or obscuring their nonrational character. Few will quarrel with the abstract assertion that what is reason-

3. At 307. See also id. at 155 ("Law, a bastion of Apollonian values, is problematic for anyone whose outlook is Dionysian"). 


\section{LAW AND SOCIAL INQUIRY}

able is preferable to what is unreasonable. However, the ideological function of the reason/passion distinction is to identify certain attitudes and beliefs with reason itself-it is a method of denying the existence of one's own passions or prejudices by clothing them in the garb of science, natural law, biological necessity, economic analysis, reasoned elaboration, neutral principles, or what have you. In this way one becomes the apostle of reason, and one's adversaries are seen as childish, immature, unrealistic, hotheaded, unscientific, or simply illiterate.

The same process of denial applies to the characterization of social institutions and practices. For example, if law is identified with reason, something else must be identified with nonreason or passion. Otherwise the distinction would dissolve. Thus, the undesirable characteristics of nonreason are projected away from what is identified with reason (law) and projected onto what law is opposed to (politics). In this way the troubling aspects of law are seen as outside of law. One thus avoids recognizing that law might share any of the disagreeable characteristics associated with passion-that a system of law could also be unreasonable, prejudicial, or oppressive in character. ${ }^{4}$ Thus, to associate authority, law, economics, and so on with the forces of reason is not only a means of justifying these concepts and simultaneously subordinating their opposite numbers, it also serves the ideological function of concealing or denying their unpalatable characteristics by projecting them onto their opposites. ${ }^{5}$

Once we understand these governing oppositions-reason over passion, and "reasonable" forms of passion over less "reasonable" forms-the ideological strategy of the book becomes easier to understand. For example, literary theory cannot be a science, but the more objective and methodical the better; conversely, the wilder and more rebellious the form of literary interpretation, the less Posner likes it. This tendency underlies his disdain for deconstructive literary criticism: "[I]n its assault not only on the inherent authority of speaker and writer but on the inherent authority of the text itself . . . deconstruction is Romanticism at its most rebellious." 6 Much of the book simply recapitulates this hierarchical ordering. Yet we must add one final piece to the puzzle before we can truly

4. Conversely, it downplays the possibility that the thing opposed to law, politics, could be in the service of enlightened goals.

5. See, e.g., Torres and Brewster, "Judges and Juries: Separate Moments in the Same Phenomenon," 4 Law \& Inequality 171, 181-85 (1986), in which the authors contend that traditional characterizations of the jury as emotional, nonrational, and unreliable serve to suppress recognition of the prejudices and attitudes of judges in the law of judges and juries.

6. At 215-16. Consistent with this tendency, Posner also views critical legal studies theorists who have adopted deconstructive techniques as espousing a form of Romanticism: "[S]ince the critical legal studies movement wants to shock, it too flaunts the banner of deconstruction." Id. at 215. This is one example of the metaphor of the unruly, rebellious child (symbolic of the dangerous side of Romanticism, which must be suppressed or subordinated) that appears in Posner's discussions of critical legal studies. See also id. at 358 ("Although many law professors find the critical legal studies movement appalling in its 
understand the book's underlying ideology. The depiction of the world as a struggle between reason and passion, or between authority and anarchy, has consequences for the legal order as well. Posner thinks it important to preserve the inherent authority and autonomy of law, which he sees as based upon reason. Yet the authority and autonomy of law is established through its differentiation, first from overt political struggle, and second, from other academic disciplines.

These challenges to the autonomy of law have similarities, but it is important to see how they are also distinct, because Judge Posner's attitude towards each is distinct. To the extent that law is just another form of political struggle, it loses its rule-like, impartial aspects. It loses the legitimacy that comes from the belief that ours is a rule of law and not of persons. Law retains a superior authority to politics only to the extent that it can separate itself from politics, or can mediate political struggles within a legal arena that is not ultimately subservient to politics.

The rise of interdisciplinary studies also involves a challenge to legal authority, but of a quite different sort. Interdisciplinary studies pose a challenge to the ability of lawyers to understand and resolve legal problems in wholly legal terms. To the extent that the law depends upon a particular extralegal discipline (say economics), that discipline gains intellectual authority at the expense of law. By having important and interesting things to say about law, other disciplines diminish the authority of legal theorists to solve legal problems without recourse to aid from other disciplines. If economics can so supplement law, then legal analysis may not be complete without the benefit of economic analysis. Law may ultimately become parasitic or dependent upon the insights of economics.

These challenges to the authority of law and the autonomy of legal discourse are related historically. They were united in the attacks on the legal process school of the 1950s.? Posner was influenced both by that

political radicalism and childish incivilities, it looms too large on the contemporary horizon to be ignored.") (footnote omitted).

7. The legal process school is most often associated with professors Henry Hart and Herbert Wechsler. The legal process scholars accepted the legal realist view that adjudication could not be mechanical and apolitical-that it inevitably raised substantive choices of public policy. However, they argued that the legitimacy of law and its autonomy from politics could be preserved by ensuring that substantive choices were made by the appropriate institutional decision-makers following appropriate procedures of decision. For example, constitutional adjudication by judges should involve reasoned elaboration of neutral principles of decision, see Wechsler, "Towards Neutral Principles of Constitutional Law," 73 Harv. L. Rev. 1 (1959); Hart, "The Supreme Court, 1958 Term-Foreword: The Time Chart of the Justices," 73 Harv. L. Rev. 84 (1959), and lawyers should apply nonpolitical craft values in making and evaluating legal arguments. Critics of the legal process school noted that process based arguments were often substantive in disguise, that there were few truly neutral principles of judicial decision, and that legal reasoning and argument could not be understood in isolation from social science and political and cultural practices. For a discussion of the governing ideology of the legal process school, and reactions to it, see 
school and by the attacks made on it, as he explains in a thoughtful essay written for the Harvard Law Review's one hundredth anniversary:

Until [the early 1960s] the autonomy of legal thought was the relatively secure, though periodically contested, premise of legal education and scholarship. It is no longer. I am particularly conscious of this change because I was educated towards the end of an era in which law-the attack of the legal realists having been blunted-was confidently regarded as an autonomous discipline, and because the law school I attended epitomized this conception (I graduated from the Harvard Law School in 1962); yet much of my professional energy since has been devoted to opposing this conception. ${ }^{8}$

Posner's embrace of law and economics must be understood in this light. The attacks on the legal process school convinced many scholars of Posner's generation that law could not retain its autonomy from politics merely by insisting that legal discourse was unrelated to political discourse. Although, as Posner points out, the normative consensus in the academy of the 1950s obscured the issue, succeeding events made it abundantly clear that legal discourse had unmistakably political overtones:

The spectrum of political opinion in law schools, which in 1960 occupied a narrow band between mild liberalism and mild conservatism, today runs from Marxism, feminism, and left-wing nihilism and anarchism on the left to economic and political libertarianism and Christian fundamentalism on the right. Even if we lop off the extremes, a broad middle area remains, running from, say, Ronald Dworkin on the left to Robert Bork on the right-both entirely respectable, "establishment" figures who, however, are so distant ideologically from each other that there is no common ground of discourse between them. We now know that if we give a legal problem to two equally distinguished legal thinkers chosen at random we may get completely incompatible solutions; so evidently we cannot rely on legal knowledge alone to provide definitive solutions to legal problems. ${ }^{9}$

The failures of legal process theory thus made clear to Posner that law could not preserve its authority and autonomy from politics on its own. It needed help from some outside source. This explains to a large degree the turn to economic analysis as a means of settling disputes about the answers to legal questions. Posner thus rejected the position of his intellectual $\mathrm{Fa}$ -

Amar, "Law Story," 102 Harv. L. Rev. 688 (1989); Peller, "Neutral Principles in the 1950s," 21 Mich. J.L. Reform 561 (1988); G. White, Pattems of American Legal Thought, 137-53 (1978).

8. Posner, "The Decline of Law as an Autonomous Discipline 1962-1987," 100 Harv. L. Rev. 761 (1987).

9. Id. at 766-67 (footnote omitted). 
thers-the legal process scholars-by abandoning the project of establishing the authority and autonomy of law through legal concepts alone. Yet, interestingly, he reinstituted their project by establishing the source of autonomy and authority in economics, which he saw as the "hardest" of the social sciences.

Thus, Posner's rebellion against his intellectual Fathers also involved a form of identification with their underlying goals. Where the legal process scholars thought that legal problems could be solved through reasoned elaboration of legal concepts, Posner now proposed that legal problems could be solved through the elaboration of economic ones. Where the legal process scholars emphasized the neutrality and rigor of "craft values" as the source of good legal analysis, Posner now substituted the neutrality of economic policy science. Economics became a "craft" or a way of thinking and analyzing that could be taught by law professors and passed along to their students just as the skill of "thinking like a lawyer" had been passed along by a previous generation of legal scholars. ${ }^{10}$

Yet Posner's rebellion from and identification with his legal Fathers created new problems. In order for economics to become the new source of legal authority and autonomy, it was necessary for economics to establish its mastery in all of the areas that law regulated and in which "reasoned elaboration"-i.e., legal reasoning-had previously claimed competence. Luckily, it was not difficult for Posner to convince himself that economics could fill the bill when it was reinterpreted as a general science of human behavior:

Economics not only has become more rigorous since the 1950s, but it has branched out from market to nonmarket behavior, thus taking in the subject matter of most interest to legal thinkers. It has also become more empirical. Not only is there today a well-developed economic theory of crime, but economists have measured the effects of punishment on the crime rate more rigorously than other social scientists, or lawyers, have ever done. There is an economics of accidents and accident law, of the family and family law, of property rights and property law, of finance and corporations, even of free speech and the first amendment, and so on through almost the whole law school curriculum. In several important fields ... the economic perspective either is already dominant or will soon be, when the older professors and practitioners retire. In other important fields ... the economic approach is making rapid strides. In still others, such as criminal law and family law, the traditionalists retain the upper hand-but for how long, who can say?"1 (1980).

10. See Horwitz, "Law and Economics: Science or Politics?" 8 Hofstra Lo Rev. 905

11. Posner, 100 Harv. L. Rev. at 767-68 (footnotes omitted). 
Crucial to Posner's project, then, was the belief that economics could be the new master discipline, itself autonomous, but which might explain results in other nonautonomous disciplines like law. In this way Posner could remain faithful to the goal of preserving legal authority and autonomy from political struggle while simultaneously being a champion of interdisciplinary studies. The legal process school had argued that law was not politics; it was a neutral, apolitical craft of reason. Posner now argued that law was not politics; it was economics, and economics was not politics, it was a neutral, apolitical science of reason.

This strategy intersects with the ideological privileging of reason over passion at several points. Law is to reason as politics is to passion. If reason is to retain its authority, passion (politics) must be subordinated to reason (law); law (reason) must not ultimately depend upon or be just another form of politics (passion). Yet law cannot by itself provide a rational discourse that would distinguish legal reasoning from legal politics. Thus, economics plays the role of the mature, realistic, impartial, and scientific discourse that supports and preserves the rationality of law from the threats of passion (politics). Economics is the "reason behind the reason" of law-the rational foundation that protects law from politics and allows politics to be subordinated to the rule of law.

Yet to establish economics as a master discipline requires that Posner must do for economics what earlier generations of legal scholars attempted to do for law. To preserve the authority of economics (and thus law) now requires the preservation of the autonomy of economics from politics and from other disciplines. If economics is not a science, if it is just another form of politics, economic debates could become just as contestable and political as legal ones. Moreover, to provide a secure foundation for the authority of law, economics must be able to explain law in economic terms without any substantial assistance or competition from other disciplines.

Posner's strategy thus requires him to subordinate the authority of other disciplines that might claim to speak as forcefully about law as economics does. First, other disciplines might demonstrate the political character of legal discourse or, worse yet, the political character of economic discourse. This would threaten to breach once again the wall that separates law from politics, which was shored up by the explanation of law in economic terms. Second, if law was as beholden to philosophy or sociology as it was to economics, the reasons why a scholar chose to approach law from the standpoint of economics as opposed to philosophy or sociology might themselves be analyzable in terms of politics or ideological bent. One might be able to ask whether law and economics was the favored mode of discourse for a particular group (say, economic libertarians) because it more easily allowed them to "demonstrate" the soundness of their favorite policies and falsely claim scientific authority for them. 
Hence, although Posner portrays himself as the champion of interdisciplinary values, his ideological program requires that all other disciplines be subservient or ancillary to economics, lest they upset the carefully reestablished authority and autonomy of law. Disciplines like literature must be shown to be either irrelevant to politics and law, unable to generate interesting insights different from those produced by law, or else able to produce only insights that are already subsumed under a more generalized economic understanding.

Posner's strategy in this book now becomes clear: It is to reinterpret literature and literary theory in any way that is not relevant to political and social issues. The more that literature has to do with power or social ordering, the more potentially relevant it would be to law, and the greater its potential competition with economics. The more literature and literary theory are seen as trivial, apolitical, and merely forms of entertainment, the more easily they fit into Posner's ideological scheme. Thus, it is no wonder that throughout this book, where literary interpretations threaten to speak about politics, they are dismissed as bad interpretations, and where literary theory threatens to merge with social criticism, it is dismissed as bad theory, or at least out of the mainstream of critical practice.

It is important to recognize that even though politics and literature are both associated with passion (when either is opposed to law), the strategy of separation between politics and literature is also linked to the reason/passion distinction: In order to preserve the authority of reason, passion must be devalued and its dangerous aspects dismantled or eradicated. One must either (1) endeavor to depict forms of passion as less powerful or authoritative than forms of reason, or (2) emphasize the importance of the values of reason over those of passion precisely because one admitted that passion was so threatening to reason. The preservation of the autonomy of law from politics involves the latter strategy; the separation of politics from literature involves the former.

Hence, if reason is to law as passion is to literature, literature must be disempowered through description. One way to do this is to distinguish it from the kind of "passionate" activity that is conceded to have powerpolitics. Thus, although politics is more "passionate" and less "reasonable" than law, one views politics as a mature, serious endeavor that involves questions of public power. Literature, on the other hand, is seen as entertainment, trivial and ancillary, and concerned only with private pleasures. To establish a distinction between politics and literature (reinterpreted as entertainment) is to recapitulate the distinction between what is important, serious, public, and powerful and what is trivial, carefree, private, and ineffectual.

Most of the problems with Law and Literature: A Misunderstood Relation can be traced to these major ideological themes: (1) the preference for 
reason over passion and reasonable passion over unreasonable passion, and (2) the need to subordinate other disciplines to economics and, where possible, to domesticate and emasculate them. What is important to understand, however, is that these difficulties are not simply mistakes by Judge Posner. They are part and parcel of his project-they are what holds the entire enterprise of the book together. If, for example, as I shall argue later on, it appears that Judge Posner misunderstands how literary theory has changed since 1957 (the year Northrop Frye's Anatomy of Criticism was published), it is not just an adventitious error of judgment. Rather, his conception of politics simply will not allow him to interpret literary theory in that way. Thus, the most interesting thing about Law and Literature: A Misunderstood Relation by Richard Posner is how the book uncannily reenacts its own title-how the relation of law and literature is systematically misunderstood by Richard Posner. What follows are accounts of how this systematic misunderstanding is manifested in various aspects of the book.

\section{THE USES OF LITERARY THEORY}

The threat to legal authority from the importation of literary theory is stated most clearly by Posner himself. He begins his discussion of law and literary theory by noting that:

to an increasing extent literary critics-especially those who practice deconstruction ... - and academic lawyers, especially those associated with the critical legal studies movement, contend that the interpretation of literary and legal texts is deeply problematic, and maybe even impossible.

$\cdots \cdots$

If literary scholars and critics decide that meaning cannot be extracted from literary texts but only be put into them, should not lawyers, too, give up the pretense of interpreting statutes and the Constitution and admit that what they are doing is making, not finding law? If so, "judicial activists" no longer need apologize for reading things into the Constitution that do not seem to be there; that is simply the nature of what we naively call "interpretation." Better to say "construction"- and mean it literally. (At 209-10, footnotes omitted)

What is notable in this passage is how Judge Posner sets his agenda. The relevance of literary theory to law is in suggesting novel methods of interpretation. The danger of literary theory, as advanced by deconstructionists and critical legal studies scholars, is that interpretation may be considered nothing more than free creation; that it will not be constrained 
by what is being interpreted. Understandably, Posner views this as a potential threat to the autonomy of law from politics.

Yet by stating the issues in this way Posner has immediately stacked the deck so that he can deal himself a hand of four aces some 20 pages later. If the appropriate application of literary theory to law is to tell us how to interpret statutes, and we cannot read statutes like poems, then literary theory must be essentially irrelevant to legal issues. Similarly, if the rule of law requires that texts constrain legal actors, and if modern literary theory does not provide us with an explanation for that constraint, well then, so much the worse for modern literary theory. Posner then goes on for 20 or 30 dreary pages repeating pretty much the same two things: Poems and statutes serve different social functions, and the rule of law requires constraint by those with power-they cannot simply be entrusted to make up the rules as they go along. It is not surprising that he comes to the conclusion that literary theory has very little to tell us about law. Indeed, in his defense of a pragmatic, commonsense theory of reading statutes, which he calls intentionalism (but which is quite different), he tells us very little that is new or interesting. One wonders what all the fuss was about in the first place.

Behind Posner's argument, however, lie a number of controversial (and ultimately incorrect) assumptions about what literary criticism is, what literary critics do, and what separates literary theory from other disciplines like philosophy, linguistics, and sociology. These assumptions allow him to ignore other aspects of literary theory that may have a great deal to say about the social practices that we collectively refer to as law. This strategy of avoidance, in turn, is an integral part of his attempt to separate literary theory from its dangerous and substantive aspects-to domesticate and subdue it-so as to avoid the conclusion that it has serious claims that legal scholars should pay attention to.

\section{A. Posner and the New Critical Paradigm}

The clearest example of how Posner attempts to domesticate literary theory is through his adoption of a particular perspective on literary theory, which we may as a shorthand refer to as the New Critical paradigm. It is named after the New Critics, whose dominance of literary theory before World War II resulted in an equally dominant reaction by literary critics in later years. The New Critics were noted for their belief that a work of art should be interpreted as a distinct, coherent unity, which could be understood in and of itself, without substantial recourse to biographical details about the author or the larger social or political context in which the work 
was created or read. ${ }^{12}$ In many ways, modern literary theory can be understood as a series of rejections of one or more premises of New Criticism. Therefore it is both illuminating and amusing that Judge Posner views New Criticism (or rather a more eclectic version thereof) as establishing the standard form of critical practice. ${ }^{13}$

In this analysis of the situation Posner is both right and wrong. He is right that many contemporary critics still employ aspects of New Criticism-for example, the close reading of texts-in their work. He is wrong, however, in three respects: First, it is not true that New Criticism is the dominant mode of critical practice in this country; if anything the dominant trend of the last 25 years has been away from it. ${ }^{14}$ Second, Posner is mistaken in his underlying assumption that to the extent that other, newer visions of critical theory do not fit easily within the paradigm of critical practice envisioned by New Criticism, they are inferior and therefore to be disregarded. Third, and most important, Posner is wrong to assume that the most appropriate applications of literary theory to law must be those that fit most easily within the boundaries set by New Criticism. In fact, the opposite is true. Those critical theories that reject aspects of New Criticism are most applicable to legal and political problems; only by dismissing these out of hand is Posner able to avoid acknowledging their relevance to law.

One of the most important aspects of New Criticism was its establishment of a paradigm about the purposes of literary theory, an issue that is distinct from the question of what sources are to be consulted in interpreting literary works. Within this paradigm, the purpose of literary criticism is to provide a series of interesting interpretations of literary texts. Thus, literary theory is the study of how to discover and adopt the right methodology of interpreting these literary works so as to produce more interesting

12. At 218-23. Posner rightly points out the existence of many different positions among the persons who today are referred to collectively as New Critics.

13. Id. at 223. Posner's version of New Criticism, which he refers to as Eclectic New Criticism, "means simply the close reading of a work of literature conceived of as an aesthetic rather than a didactic discourse, using whatever aids to such reading lie to hand."

14. For example, in Hazard Adams's and Leroy Searle's collection of works of contemporary critical theory, Critical Theory Since 1965 (H. Adams \& L. Searle, eds. 1986), no space is given at all to what might be called New Critical scholarship-and when New Criticism is mentioned, it is only as a foil to what are considered to be the dominant trends and movements in critical theory-reception theory, reader-response theory, deconstruction, (both by Derrida and other members of the Yale School), myth criticism, Foucauldian criticism, psychoanalytic criticism, feminist criticism, and Marxist aesthetics. New Critical works did play a prominent role in Adams's anthology of earlier critical theory, Critical Theory Since Plato (H. Adams, ed. 1971). But this simply demonstrates all the more that Posner is somewhat behind the times.

For a view of post-1957 criticism as an attempt to come to terms with the "imposing and repressive father figure" of New Criticism, see F. Lentricchia, After the New Criticism (1980). 
readings of them. ${ }^{15}$ This is the paradigm of literary practice that Posner assumes throughout the book. Yet it is a paradigm designed to deter interdisciplinary study and to downplay the political and social relevance of literary criticism. ${ }^{16}$

Just as the history of modern literary criticism consists of a series of rejections of the New Critics' approved methods of interpretation, this history can also be understood as a gradual rejection of the purposes of literary theory assumed by New Criticism. The rejection of this paradigm - which concerns not the question of how to read texts, but of why we read them-is one of the most important developments in literary theory in the last 30 years. Yet it is a development that Judge Posner has strangely overlooked. However, if one insists upon understanding all subsequent attempts at interpretive theory-how texts should be read-in light of the New Critical paradigm of why we interpret literary texts, one will completely misconceive developments in modern literary theory, and its increasingly intimate connections with philosophy, sociology, psychoanalysis, and intellectual history.

Much of modern literary theory is concerned not with literary criticism in the New Critical sense, but with social criticism practiced through the medium of literature. For modern literary criticism is inextricably linked with

writings within a domain as yet unnamed but often called "theory" for short. This domain is not "literary theory," since many of its most interesting works do not explicitly address literature. It is not "philosophy" in the current sense of the term, since it includes Saussure, Marx, Freud, Erving Goffman, and Jacques Lacan, as well as Hegel, Nietzsche, and Hans-Georg Gadamer. It might be called "textual theory" if text is understood as "whatever is articulated by language," but the most convenient designation is simply the nickname "theory."17

By clinging to a New Critical paradigm of the purposes of literary theory, Posner avoids recognizing that literary theory has changed greatly in recent years, and that this change is not simply a deviation from a standard "correct" practice to which literary critics will no doubt return once they regain their senses. Of course, as a cultural and political conservative, Posner might hope for such a reemergence of New Critical values, but the world has passed them (and him) by. Most literary criticism that is considered on the cutting edge of the field is "theory" of the sort described

15. See J. Culler, The Pursuit of Signs: Semiotics, Literature, Deconstruction 4-5 (1980).

16. See Tompkins, "The Reader in History," in J. Tompkins, ed., Reader Response Criticism: From Formalism to Post-Structuralism 219-23 (1980).

17. J. Culler, On Deconstruction 8 (1982). 
above. It combines linguistics, intellectual history, cultural criticism, and moral philosophy, and it cannot be encapsulated into a single traditionally understood academic genre.

As an example of this new brand of literary theory, consider one of Edward Said's most celebrated works, Orientalism. ${ }^{18}$ Orientalism shows us how European writers and scholars interpreted and constructed the meaning of the Orient (especially the Orient of the Near East) - as a mysterious, dark, and duplicitous thing to be contrasted with the West and subjugated by it. Said, who has been influenced by the French historian of ideas, Michel Foucault, is interested in showing us how ideas shape power-how the appropriation of the Orient, its recreation in an image that suited Western minds, justified its occupation, subordination, and domination.

Said's work does not fit into the New Critical paradigm of literary criticism, for he is not interested in producing imaginative readings of literary works. Yet Posner could hardly deny that Said is a highly respected literary critic. In fact, Posner's task in this book is to do to literature something like Said argues Western writers did to the Orient-to encapsulate and dominate it by definition and description. Posner's depiction of literary theory presents us with an effete, powerless discourse with no social implications, a source of passive entertainment but not of political enlightenment.

\section{B. Misinterpreting Interpretive Theory: Posner on Poststructuralism}

These issues reemerge when Posner turns his sights to poststructuralism, which he conflates with the reader-response movement. In his view, "[t]he thread that connects the various schools of post-structuralism is their determination to reverse the traditional primacy of author over reader" (at 216). What is interesting about this conflation is that at the -same time Posner acknowledges Foucault as a poststructuralist (at 216 n.6). As is so often the case in this book, it is what Posner omits in his descriptions rather than what he includes that is most revealing. Foucault's famous essay, "What is an Author?"19, which Posner cites, can be understood on many levels-for example, it discusses the history of the idea of authorship and the ways in which the author's intention has been connected to claims of author-ity about a text's meaning. ${ }^{20}$ But what this essay is certainly about, and what ties it to the corpus of Foucault's

18. E. Said, Orientalism (1978).

19. Foucault, "What Is an Author?" reprinted in M. Foucault, Language, Counter Memory, Practice 113 (1977).

20. For an excellent discussion and application of Foucault's essay, see Boyle, "The Search for an Author: Shakespeare and the Framers," 37 Am. U.L Rev. (1988). 
thought, is how discourses create power. Foucault argues that the concept of an "author" allows a culture to shape and control the possible meanings that a text could have, just as later he would argue that discourses of sexuality shape and control allocations of power in society. ${ }^{21}$ Yet this is precisely the aspect of poststructuralist criticism that Posner does not want to acknowledge. For if modern literary criticism and literary theory were about how discourse shapes power, the political ramifications of literary theory would be too obvious to avoid. Thus, by recasting poststructuralism as involving the question of whether authors or readers are more important to interpretation, Posner forces all poststructuralist criticism to be judged through a New Critical paradigm of interpretation, and it is no surprise that it is found wanting. This is a serious misunderstanding of why the move to poststructuralism occurred, and it gives one pause to think that Judge Posner has read (or at least has cited) so many poststructuralist works and yet does not seem to have gotten the point. But again, this misapprehension is not accidental. The systematic misunderstanding of poststructuralism is necessary to preserve the political quiescence of literary criticism that is essential to the enterprise of domestication. One cannot domesticate Foucauldian criticism once one understands what Foucault is about.

Posner could, of course, respond that to the extent that literary critics use Foucault's theories in their work, they are no longer practicing literary theory, and so the importation of those ideas into legal theory cannot justly be called law and literature. But this begs the question in a rather obvious way. Certainly Edward Said is better equipped to tell us what is or is not literary criticism than is Richard Posner. Similarly, Posner might argue that any literary criticism which goes outside of the New Critical paradigm is simply bad criticism and not worth concerning ourselves with. But again, it is hard to see this kind of argument as anything other than self-serving. Posner does not like the new forms of evaluative criticismpsychoanalytic criticism, feminist criticism, and Marxist criticism-precisely because they have cultural and political overtones. It seems circular to argue that anything that has such overtones cannot constitute literary theory because it does not comport with Posner's ideal of it, and equally circular to say that importation of any such form of criticism to law cannot be law and literature.

\section{The Omission of Structuralism and Semiotics}

Although Posner discusses poststructuralism as a movement, he gives little attention to the movement that immediately preceded it, structural-

21. M. Foucault, The History of Sexuality (1978). 
ism. ${ }^{22}$ This omission is troubling for two reasons. First, structuralist methodology has generated a substantial body of literary criticism. ${ }^{23}$ Second, Posner's omission of structuralism seriously undermines his claim that literary theory has nothing of importance to add to the study of law. If any development in critical theory has had a significant impact on legal scholarship, it is structuralism. The methodology of structuralism-the search for recurring relationships in legal discourse-has greatly affected the critical legal studies movement. ${ }^{24}$ The influence of structuralism remains very much alive today, even after most CLS scholars have assimilated the poststructuralist critiques of structuralist methodology.

Posner also does not even mention the more general study of semiotics, the theory of systems of signification, which encompasses both structuralism and some forms of poststructuralism. ${ }^{25}$ Semiotic analyses have

- 22. Posner mentions structuralism in passing but does not discuss it: See R. Posner, Law and Literature, at 220 n.16 and cf. id. at 19 n.30 (mentioning Northrop Frye's classifactory criticism).

23. E.g., R. Barthes, Elements of Semiology (1967); R. Barthes, Writing Degree Zero (1967); A. J. Griemas, Semantique Structurale (1966); V. Propp, The Morphology of the Folktale (1968). For general introductions, see J. Culler, Structuralist Poetics (1975); T. Hawkes, Structuralism and Semiotics (1977); D. Lodge, Working with Structuralism (1981); R. Scholes, Structuralism in Literature: An Introduction (1974).

Posner's omission of structuralism is especially significant because structuralist criticism is completely at odds with the New Critical paradigm of why one reads literature. For the structuralist

the interpretation of literary works is only tangentially related to the understanding of literature. To engage in the study of literature is not to produce yet another interpretation of King Lear but to advance one's understanding of the conventions and operations of an institution, a mode of discourse.

J. Culler, The Pursuit of Signs: Semiotics, Literature, Deconstruction 5 (1981).

24. One of the seminal articles of the CLS movement, Kennedy, "Form and Substance in Private Law Adjudication," 89 Harv. L. Rev. 1685 (1976), is clearly influenced by structuralism. Indeed, several of Duncan Kennedy's writings up to 1984 can be viewed as applications of structuralist methodology to legal problems. See Kennedy, "The Structure of Blackstone's Commentaries," 28 Buff. L. Rev. 205 (1979); Kennedy, "Distributive and Paternalist Motives in Contract and Tort Law, with Special Reference to Compulsory Terms and Unequal Bargaining Power," $41 \mathrm{Md}$. L. Rev. 563 (1981). It is especially remarkable that Posner did not consider the influence of structuralist methodology on legal theory, given Kennedy's prominence in the critical legal studies movement. Other structuralist or semiotically influenced works include Balkin, "The Crystalline Structure of Legal Thought," 39 Rutgers L. Rev. 1 (1986); Balkin, "Taking Ideology Seriously, Ronald Dworkin and the CLS Critique," 55 UMKC L. Rev. 392 (1987); Boyle, "The Politics of Reason: Critical Legal Studies and Local Social Thought," 133 U. Pa. L. Rev. 684 (1985); Heller, "Structuralism and Critique," 36 Stan. L. Rev. 127 (1984); Katz, "Studies in Boundary Theory: Three Essays in Adjudication and Politics," 28 Buff. L. Rev. 383 (1979); Kelman, "Interpretive Construction in the Substantive Criminal Law," 35 Stan. L. Rev. 591 (1981). Structuralist methodology also informs the present article, which interprets the ideology underlying Posner's book in terms of interrelated sets of opposed ideas.

25. See R. Barthes, supra, note 23; T. Hawkes, supra, note 23; K. Silverman, The Subject of Semiotics (1983); U. Eco, A Theory of Semiotics (1979). The classic application of semiotic theory to cultural criticism is R. Barthes, Mythologies (1972). Semiotic analyses have been applied to such diverse cultural artifacts as television shows, kitchen appliances, and architecture, see, e.g., D. Preziosi, The Semiotics of the Built Environment: An Introduction to Architectonic Analysis (1979). 
already informed much legal scholarship, both within critical legal studies and without it. ${ }^{26}$ One can understand Posner's reluctance to acknowledge the worth of CLS scholarship that he disagrees with. Nevertheless, this does not justify his neglect of an important body of literature in CLS that is based upon structuralist and semiotic methodologies. If Posner wishes to explain in detail why structuralism and semiotics do not assist legal theory, he is certainly free to do so. But he has not done so here, and he may not simply pretend that this body of work did not exist and then make the strong claims about the value of literary theory to law which he puts forth in this book. ${ }^{27}$

\section{Posner on Deconstruction}

Similar problems of omission and selective description occur in Posner's treatment of one of the most prominent forms of poststructuralist theory today-deconstruction. As Posner sees it, deconstruction is a challenge to what he refers to as the orthodox theory of meaning and communication: People use signifiers (writing or speech) to express concepts that they derive from their perceptions.

[Deconstruction] insists that to regard those properties of signifiers that impede communication as secondary is arbitrary and culturebound rather than, as the orthodox theorists suppose, logical or "natural." It is just as logical, just as natural, deconstruction insists, to subordinate the communicative function of discourse to the communication-impeding effects of the signifiers that the speaker or writer uses, and thus to attend to the "play of the signifiers," which is to say to the relations between the signifiers and other concepts besides the one intended to be signified.

But to say that the properties of signifiers that make them an imperfect medium of communication are as interesting or important as

26. For non-CLS adaptations of semiotics, see B. Jackson, Semiotics and Legal Theory (1985); R. Kevelson, The Law as a System of Signs (1988).

27. Again, Posner might make the same objection as before-that to the extent that one applies structuralist and semiotic insights to law, one is no longer doing literary theory, but instead is doing philosophy, or anthropology, or the sociology of knowledge. The answers to this objection should by now be familiar: First, this objection does not confront the substance of the contributions of literary theory, but merely attempts to define them out of existence. Second, structuralist and semiotic literary theory is concerned with the sociology of knowledge-this is just another example of how literary theory and other disciplines have moved closer together in the post-World War II era. Finally, this objection overlooks the fact that adaptation of a literary methodology to legal problems will require that the resulting application will almost by definition be performed on legal problems. Structuralist analyses of law cannot avoid becoming analyses of legal, social, and political concepts. Indeed, what else could one expect to occur if one applied a methodology from one discipline to the subject matter of another? 
communication-even to say that the . . . orthodox theory of language, is ungrounded or incoherent-is not to say that communication or "intersubjectivity" is impossible, and thence that no text can be interpreted in a way that will recreate in the reader's mind the (approximate) concept that the author of the text meant to convey. Therefore it is not apparent why deconstruction should be thought to disestablish the interpretability of statutory and constitutional texts; nor have Jacques Derrida's self-appointed representatives in the American legal community given any reason why it should. (At 212-13)

Amusingly, in the course of defending the proposition that intersubjective understanding is possible, Posner demonstrates that he has misunderstood the texts on deconstruction he has read or cited as he attempts to convey his (mis)understanding to us. Indeed, although Posner argues that deconstruction (or rather his version of it) is wrong to elevate impediments to communication over communication, and understanding over misunderstanding, these impediments and this misunderstanding become crucial to the success of his argument that deconstruction has nothing to offer lawyers. This is ironic because deconstruction is concerned with how the things we denigrate, exclude, or otherwise marginalize turn out to be most essential to our thought or to what we seek to accomplish. Posner's argument thus becomes as much an example of deconstruction as a criticism of it.

When I say that Posner has misunderstood deconstruction in the above passage, I do not mean to say that he is totally wrong. Rather, what makes his argument seem plausible is that he has gotten it almost right. It is less what Posner misrepresents than what he does not represent, that is, what he leaves out, that results in his misunderstanding and misdescription of deconstructive theory.

Deconstruction is a series of philosophical practices first articulated by Jacques Derrida and his colleagues. These techniques of analysis were occasionally used, in limited fashion, by other persons before Derrida, which often leads to the familiar "speaking prose" criticism ${ }^{28}$ - because we can find deconstructive arguments in Hume, deconstruction provides us with nothing interesting or new. However, the achievement of the deconstructive movement has been to recognize that these techniques have a more general form, which applies whether one is doing philosophy, literary criticism, or social science. Thus, even if Hume made arguments that we would now recognize as deconstructive, he did not understand that his arguments had a general character that could be applied in similar fashion

28. The idea of "speaking prose" is a reference to the Moliere character M. Jourdain, who, after being told the difference between prose and poetry, remarked that he had been speaking prose his whole life without realizing it. 
to other areas of human discourse. ${ }^{29}$

The generality of the deconstructive approach may not at first be apparent because most deconstructive work in this country (and most of the deconstructive works that Posner has cited) involve readings of literary texts. Nevertheless, it is a serious mistake to claim that deconstructive techniques are necessarily or even primarily concerned with how to interpret works of literature. This is as serious a mistake as to assume (as Posner apparently does) that Derrida's Of Grammatology ${ }^{30}$ is a book primarily about the distinction between speech and writing. Posner's "literal" conception of deconstruction (a pun seriously intended) is a misunderstanding well worth studying in light of his general project of domestication.

One of the most often used deconstructive techniques, for example, is the analysis of conceptual systems in terms of hierarchies of value or priority. This is the central claim in Of Grammatology: that Western thought has repeatedly constructed its conceptual systems to privilege some form of "presence" over "absence." The elevation of speech over writing is both a metaphor for and an example of this privileging, which Derrida calls "logocentrism." As Derrida notes

What interested me then ... was ... a kind of general strategy of deconstruction.

[W]e must proceed in a double gesture. [First, we must] recognize that in a classical philosophical opposition we are not dealing with the peaceful coexistence of a vis $\grave{a}$ vis [the first term versus the second], but rather with a violent hierarchy. One of the two terms governs the other (axiologically, logically, etc.), or has the upper hand. To deconstruct the opposition, first of all, is to overturn the hierarchy at a given moment. To overlook this phase of overturning is to forget the conflictual and subordinating structure of opposition.

[Second], we must also mark the interval between inversion, which brings low what was high, and the irruptive emergence of a new "concept," ... that . . . never could be, included in the previous regime. ${ }^{31}$

In this passage, Derrida could not be clearer (in contrast to his usual practice) that deconstruction is not simply confined to the interpretation of literary texts. Curiously, although Posner cites this work as illustrative of deconstruction, he does not appear to draw from it the obvious conclu-

29. Of course, to be perfectly consistent with deconstructive theory, I should hasten to add that deconstructionists would not claim that deconstructive techniques are always exactly the same when applied at different times to different disciplines. The claim of similarity of two instances of a practice must simultaneously carry with it an acknowledgment of variation and metamorphosis caused by the iterability of a practice.

30. J. Derrida, Of Grammatology (1976).

31. J. Derrida, Positions 41-42 (1981) (emphasis in original). 
sion-that any conceptual system-not just a literary text or a legal statute-could be deconstructed in this way. And it follows that legal doctrines or legal theories that can be translated in terms of privilegings can be deconstructed. Indeed, I have argued that most legal doctrines can be so translated, and so deconstructive techniques can be fruitfully applied to their analysis. ${ }^{32}$ Thus, scholars have, in recent years, used deconstructive techniques to analyze contract law, ${ }^{33}$ administrative law, ${ }^{34}$ analytic jurisprudence, ${ }^{35}$ American legal theory, ${ }^{36}$ and even law and economics. ${ }^{37}$ These applications of deconstructive theory to law do not depend upon any claim that intersubjective communication is impossible-indeed, they are quite removed from issues of statutory construction. ${ }^{38}$

This brings us back to the familiar objection. Deconstruction may have many interesting things to tell us about legal doctrine, but the type of deconstruction just described has very little to do with literature. If so, is Posner not justified in disregarding these aspects of deconstruction in evaluating the promise of the law and literature movement? Nothing prevents Posner from arguing that the philosophical theory of deconstruction is not what he means by the term "deconstruction," because it is not an application that is tied to the interpretation of literary texts. But again this semantical objection merely demonstrates what is wrong with his entire approach to the subject of law and literature. By narrowly construing the word, he misunderstands and obscures the philosophical theory that spawns and justifies the literary practice of deconstruction in the first place. Moreover, he assumes the very point he is arguing for-that the relevance of law and literature must consist solely in the application of methods of reading literary texts to reading statutes and constitutions. He

32. Balkin, "Deconstructive Practice and Legal Theory," 96 Yale L.J. 743, 761-64 (1987).

33. Dalton, "An Essay in the Deconstruction of Contract Law," 94 Yale LJ. 997 (1985); Spann, "A Critical Legal Studies Perspective on Contract Law and Practice," 1988 Annual Survey of Am. Law 223; Feinman, "A Case Study in Critical Contract Law," 1988 Annual Survey of Am. Law 273.

34. Frug, "The Ideology of American Bureaucracy," 97 Harv. L. Rev. 1276 (1984).

35. Kramer, "The Rule of Misrecognition in the Hart of Jurisprudence," 8 Oxford J. Leg. Stud. 401 (1988); Balkin, "Taking Ideology Seriously: Ronald Dworkin and the CLS Critique," 55 UMKC L. Rev. 392 (1987).

36. Peller, "The Metaphysics of American Law," 73 Calif. L. Rev. 1152 (1985).

37. Schlag, "An Appreciative Comment on Coase's 'The Problem of Social Cost': A View from the Left," 1986 Wis. L. Rev. 919; Schlag, "Cannibal Moves: An Essay on the Metamorphoses of the Legal Distinction," 40 Stan. L Rev. 929, 967-60 (1988) (appendix 3); Schlag, "The Problem of Transaction Costs" 62 So. Cal L. Rev. - (forthcoming 1989).

38. Despite Posner's arguments to the contrary, deconstruction or deconstructive techniques can help us understand our practices of reading the Constitution; using deconstruction in this way does not require us to deny the possibility of intersubjective understanding in interpreting the Constitution. See Balkin, 96 Yale LJ. at 772-85; Balkin, "Constitutional Interpretation and the Problem of History," 63 N.Y.U. L Rev. 911 (1988). But my point here is that deconstruction offers even greater possibilities in its other intersections with legal theory, which Posner does not even consider. 
neglects the possibility that the philosophical underpinnings of literary theory might be equally applicable to law. By circumscribing what may or may not appropriately be called "deconstruction," Posner not only misunderstands the term but also engages in a double maneuver-picking out particular facets of theory and dubbing them "literary theory" while excluding anything that might have substantive or political significance for law, any critical or analytical power.

\section{E. Posner as Interdisciplinary Disciplinarian}

Judge Posner's strategy, whenever he is confronted with interesting theses about interpretative theory, whether from deconstruction, poststructuralism, or hermeneutics, is to attribute them to philosophy or sociology, but not to literary theory. Thus he claims that:

This is not to deny the competence of literary theorists to participate in the debates over statutory and constitutional interpretation that are so prominent a part of legal theory today. . . . But [Stanley] Fish's own contributions suggest the limitations of literary theory in relation to legal interpretation. It is not Fish the Milton scholar who enters the lists; it is Fish the interpretive skeptic, deploying an analytical apparatus that he got from Wittgenstein.

It might seem, however, that in [Fish's] concept of interpretive communities ... we might have a clue to a mode of interpretation that would cross the law-literature divide. . . . But this tack would own little or nothing to literary theory as such, for "interpretive communities" was Wittgenstein's concept (and before him, Nietzsche's and Peirce's) before it was Fish's. (At 263-64)

In passages like these Posner's project of domestication is in full force. The easiest way to dismiss Fish's contributions to literary theory is to remark that they were also Wittgenstein's. Since Wittgenstein was a philosopher, what Fish tells us cannot be a contribution from literary theory, and therefore (by implication) Fish has no authority from within his own discipline (literary theory) to tell lawyers anything interesting about theirs. We might as well listen to other lawyers as to a literary critic like Fish. Yet it is unclear that Fish's theory of interpretive communities is made any less valuable by the fact that one can label it philosophy or the sociology of knowledge rather than literary criticism. Similar ideas can be found in Saussure; by Posner's line of reasoning perhaps Wittgenstein (if he were alive) would be telling us nothing new, and would lack authority from within his discipline (philosophy) to make this claim, since it is really an insight derived from linguistics. At this point one might well be con- 
cerned that no one will have any authority to say anything interesting, because everything will turn out to have been said first by Plato, or maybe even by Thales.

Yet what is the point of this scrupulous attention to the boundary lines of different academic disciplines, this solicitous concern over establishing the authority of members of different disciplines to teach lawyers interesting things? The question answers itself. Posner wants to deny the authority of literature to instruct lawyers about law by narrowly circumscribing what can count as literary theory. But this is quite false to the way academic studies have developed in this century. What is most remarkable about Fish's work is its demonstration that literary theory, philosophy, linguistics, and the sociology of knowledge are steadily moving together. ${ }^{39}$ Fish is a literary theorist whose greatest recent achievements have been precisely in showing that literary theory intersects with important issues in the sociology of knowledge. That is not a reason to dismiss his work, or that of literary theory in general; it is a reason to believe that interdisciplinary studies-including literary theory-do illuminate law. The fact that Wittgensteinian postanalytic philosophy, and Saussurian and Peircian semiotics converge upon and confirm what Fish is saying about literary texts is not a reason to dismiss him as a Johnny-come-lately. It is a reason to take what he has to say even more seriously.

Posner's divide and conquer strategy is annoyingly deceptive: First, by insisting on clear boundary lines that tell us what contributions come from each discipline, Posner refuses to acknowledge the increasing mutual interchange within the various disciplines we call the human sciences; thus, he endeavors to avoid the force of interdisciplinary claims in the name of interdisciplinary studies. It is no small irony that a book which purports to advance the cause of interdisciplinary studies finds itself so concerned with establishing what is or is not within a particular discipline. Second, this strategy allows him to avoid confronting the content of what Fish and other literary theorists are saying by demanding that it be said by philosophers instead. 40

39. See S. Fish, Is There a Text in This Class? (1980); S. Fish, Doing What Comes Naturally: Change, Rhetoric, and the Practice of Theory in Literary and Legal Studies (1989).

40. Indeed, one might be suspicious of Posner's glib announcement that Fish's work is warmed-over Wittgenstein, since Posner does not accurately describe Fish's contributions. He argues that

Fish uses the concept of interpretive communities not to interpret legal or literary texts but merely to state what is obvious - that there is, as a matter of empirical fact, some agreement about the meaning of each legal as of each literary text. (At 264)

But the point of a theory of interpretive communities is not that people agree on the meanings of texts. 'It is how they agree. Moreover, it is not that they agree on the meanings of texts, but how they agree on the relevant considerations to take into account when reading a text. That is why it is possible for there to be disagreement among members of the same interpretive community, a point that Fish's critics sometimes overlook. See, e.g., S. Fish, Is There a Text in This Class? 342 ("Thus, while there is no core of agreement in the 
This concern for establishing boundaries between disciplines is symptomatic of Posner's need to isolate and eliminate the threat to the autonomy of law posed by competitors to economics. One has only to contrast his treatment of other disciplines with his treatment of economics. Posner would rebel at the suggestion that much law and economics teaches us nothing new because it is just common sense, or because earlier lawyers and judges already made economic arguments, or because some philosopher or sociologist had made a similar point a century ago. Moreover, no academic boundary line is too broad for Posner to cross in the name of economics. No one is more eager to show that the result of another discipline-say evolutionary biology or sociology-is confirmed by economic science than Richard Posner, and he has never shown any hesitation about his authority to offer insights on these and any other disciplines in which economics might have even tangential significance. ${ }^{41}$ His quite different treatment of the boundary lines between literary theory and philosophy might give one pause, and suggest that the conclusions he draws are not wholly disinterested ones.

\section{THE INTERPRETATION OF LITERARY TEXTS}

All of Posner's criticisms of modern literary theory can be seen as stemming from his larger goal of domestication, or as he sees it, preserving the purity of literature from the assaults of political polemicists who want to take literature and literary theory from the realm of entertainment, and empower it with critical force. It is not surprising that Posner argues that reading literature will not help us to understand the political and social issues of the day or make us better persons (at 299-303).

These are two distinct positions. As to the latter point, I tend to agree with Judge Posner. We should not assume that the more well read people are, the more sympathetic or humanistic they will become. Indeed, for those who disagree with Judge Posner's politics, I suspect that there is no better counterexample to this proposition than Richard Posner himself. The study of Wordsworth and Dickens apparently has had no signifi-

text, there is a core of agreement (although one subject to change) concerning the ways of producing the text"). (Emphasis in original)

Moreover, Fish's point is not that people just happen to agree about how to approach particular texts. It is that these ways are systematically related to the ways they approach other texts, and also to previous ways in which people have previously approached texts. Interpretive communities are not a mere interesting happenstance-they are the result of systematic and historically understandable processes. Thus one important difference between Wittgenstein and Fish is that Wittgenstein did not propose a structuralist, or even a poststructuralist, view of how interpretive communities are constituted.

41. See, e.g., R. Posner, The Economics of Justice (1981), in which the author dabbles in anthropology and sociology, in addition to political philosophy and moral theory. 


\section{LAW AND SOCIAL INQUIRY}

cant effect on his views. ${ }^{42}$

If reading great works of literature will not necessarily make us better persons, it does not follow that studying literature is not a useful method for discussing problems of justice and social organization. As Posner himself notes at the conclusion of the book:

Most of the issues that would be covered in . . . a [law and literature] course could, it is true, be covered in a course on jurisprudence or legal process stressing the rhetoric, ethical underpinnings and dilemmas, interpretive problems, and epistemology of law. But such a course is not likely to be so vivid, memorable, and entertaining as a well-taught course in law and literature. ... [ [L]aw students who are open to the appeal that literature makes to a select few in an electronic age may find it most rewarding to address ... jurisprudential topics in a perspective shaped by works of literature. (At 358)

This is not, however, a position that Posner wants to press too seriously, and for obvious reasons. It would tend to make literature too relevant to political concerns. It would sanction the very sort of political usage of literature that Robin West has made of Kafka. Thus, Posner's basic stance on this aspect of the law and literature movement is that great literature has relatively little to teach us about current social issues.

42. This is why I believe that, despite the erudition that generally informs her work, Robin West went in the wrong direction when she tried to use Kafka to critique Posner's economic theories by showing how Kafka's characters do not act as rational self-seeking wealth maximizers. It does no good to try to use Kafka to show Judge Posner the error of his ways. Rather than explaining how different Kafka's view of choice and consent is from Posner's, she would have better spent her efforts demonstrating how much Posner's work in law and economics reminds one of Kafka. One of Kafka's most distinctive stylistic features is his matter-of-fact descriptions of the most extraordinary and dreadful events. The poignancy in Kafka's work often comes from the deliberate repression of emotional affect in his prose, so that the reader is made to feel uneasy by the oppressive deadpan of the narrative. This is less surrealism than rationalism gone rampant. It is the sort of privileging of reason over passion that gives reason a bad name. In this respect it is quite fitting that Ernst Pawel entitled his biography of Kafka The Nightmare of Reason. E. Pawel, The Nightmare of Reason: A Life of Franz Kafka (1984).

Kafka's world is "Kafkaesque" because although terrible and bizarre things happen, no one acknowledges them as such, or expresses much emotional concern. The world Posner describes, where poor people don't really value what they don't have the money to buy, $R$. Posner, Economic Analysis of Law, 11-12 (3d ed. 1986), where women apparently earn higher wages in the workplace than they would otherwise receive in order to compensate them for the "unpleasantness" of sexual harassment, R. Posner, Law and Literature, at 190-91, and where battered wives stay with their husbands because it is more efficient to do so, id. at 194-95, is Kafkaesque in this sense of the word. The only difference is that Judge Posner is not attempting to make an artistic statement through indirection. He really believes what he is saying. Of course, if the New Critics are right, his actual intentions in writing might be irrelevant and even detract from the real meaning of his work. If Judge Posner gets his way and New Critical values do make a comeback, perhaps one hundred years from now someone will stumble across his writings, and, reading his work in its most charitable light, declare him to be the greatest unconscious satirist of capitalism of the late twentieth century. 
Rather, great literature speaks to eternal concerns. ${ }^{43}$ It follows that persons who see political or social relevance in literary works are reading these works in an idiosyncratic way, and thus are misusing the literary canon. Posner's position is that

it damages literature to press it into the service of political debate. Some people think that the way to preserve literature in the twentieth century is to make it speak to twentieth-century problems. But what literature speaks to are the eternal problems of the human condition, not the specific manifestations of those problems in the politics of our century. We are apt to miss what is distinctive in works of literature if we turn them into propaganda tracts, even or perhaps especially on such urgent questions as genocide, totalitarianism, racial discrimination, and the politics of law. By insisting on the separateness of law and literature, even while exploring their interactions, we help preserve both fields. (At 356-57)

Although this passage appears to be about potential damage to literature, it is clearly also about the potential damage to the autonomy of law from politics. The best way to preserve literature turns out to be the best way to head off the threat of law and literature-to ensure that literature is not used to provoke discussion of current legal or social issues.

Posner is as good as his word in his own interpretations of literary

43. This is because for Posner, literature is defined as those works that have survived a process of competition in the literary marketplace. Although Posner states at the beginning of his book that he will omit any extended discussion of the literary canon, (at 20), the issue of what is in the canon and how it is formed dominates the entire book. In Posner's view

[i]t is no accident that literature tends to deal with basic, timeless features of literary existence. The surest, maybe the only, test of literary distinction is survival over time, a process of competitive selection in the literary marketplace. The process favors works of generality, of universality. Works that are essentially local, as most works seriously about law in the lawyer's sense are bound to be, do not fare well in this competition. (At 15)

The metaphor of competition is deliberate, for it ties in nicely with Posner's general preference for marketplace solutions to social issues. As he says, a "survival" theory of literature is "[a] theory that itself reflects an economic outlook, for economics and evolutionary biology are closely related." Id. at $357 \mathrm{n} .2$. This survival theory allows Posner to conclude that the generality of literary works (and hence their irrelevance to contemporary political and social issues) is a property of the works themselves, and not a property of the way in which successive generations of elites who determine the content of the canon have viewed these works. Thus, the construction of the canon is the result of a natural competitive process of elimination based upon what is really in the works themselves, as opposed to a reflection of cultural and political factors. So conceived, this theory of the canon seems at odds with Posner's later lament that

[m]ost law students today, even at the best law schools, have little acquaintance with the classics of Western literature. . . . partly because television and the movies have drained considerable interest away from literature; and partly because professors of literature have lost confidence in their authority to prescribe a fixed canon of classical works in the face of demands by women and members of minority groups for admission of works by members of their groups to the canon (at 360).

These developments, if anything, would seem to be evidence of the marketplace at work. 
works. Amazingly, the themes of each of the great works he discusses, from the Iliad and Hamlet to The Just and the Unjust and In the Penal Colony, turn out to be about general things like maturity or despair-anything but politics (at $61,81,98,117-18$ ). Even Billy Budd turns out to be only about law in the abstract, and even then about how important respect for legal authority is (at 162-64). Robert Weisberg sums up Posner's interpretive tendencies well:

Posner reads the classics as collective Bildungsromans [novels about coming of age], where a society sows its wild oats and adopts an ethic of mature, anti-transcendental practical reason. . . . Maturity is not just a theme but a maneuver for keeping literature, law, and other potentially unstable and related forms of discourse in safely separate categories. Maturity is the default theme. It is the thing Posner permits literature to be about when he refuses to let it be about something else which he fears would subvert the safe privileged status of literature. ${ }^{44}$

The predisposition Weisberg notes is systematically related not only to Posner's need to separate literature from politics, but also to Posner's preference for reason over passion and reasonable (read here mature) passion over unreasonable passion. We are back to Mr. Smith and the Rorschach test. No matter what work one hands Posner, it will turn out to be about maturity or, when that fails, private grief and despair. ${ }^{45}$ Posner's consistent pattern of literary interpretations poses the converse of the problem we began this essay with. It may be that Posner is correct in asserting that all of these works really are about maturity. Or perhaps his ideological commitments require him to see the same thing in each text.

Posner's views on the political uses of literature are connected not only to his self-stated "unease with Romantic values" (at 357), but also to his New Critical paradigm of literary theory. As explained before, this theoretical stance necessarily overlooks reasons why one might use literature to discuss social problems. Moreover, it is conveniently incompatible with those ways of reading texts that are best suited for drawing political and social insights from literature.

To understand this point better we should distinguish the uses one might make of literature, the purposes for which a particular work of literature was written, and the proper function of literature as announced by literary theory, which simultaneously determines the proper function of literary criticism. As to the issue of intended purpose, the various works we call literature were created for many different reasons. As proof, note that we group together as "literature" Homer's Iliad, Aristophanes' come-

44. Weisberg, "The Law-Literature Enterprise," 1 Yale J.L. E Humanities 1, 25 (1988).

45. Id. at 28. 
dies, Cicero's orations, Shakespeare's dramas, Boswell's Life of Johnson, Blake's poetry, Bunyan's Pilgrim's Progress, Pope's satires, Dickens's novels and Macaulay's essays. Even if we exclude one or two of these works from the canon of literature, the fact remains that the purposes behind a work's creation do not determine its literary status. The social context in which Aristophanes' comedies and Eliot's poetry were written, for example, should be enough to establish that later readers constructing the canon lump together a great deal of disparate material.

The distinction between the purpose behind the creation of a literary work - to instruct, to convince, or to entertain - and the function of literature as decreed by any particular literary theory follows directly from this observation. For example, the New Critics believed that an author's intentions, including the author's purpose in writing the work, were largely irrelevant to the merit or the meaning of a literary work. Thus, New Criticism itself established that literary theorists should read at least some parts of the literary canon for purposes other than for which they were created.

Yet, just as the purposes for which works of literature are written depend upon historical context, so too does the function of literature as announced by the literary theories of the day. Posner's assumptions about what constitutes appropriate literary criticism, or even what constitutes good literary criticism, would be bolstered if there were an unchanging view of the function of literature and literary criticism. But there is no such unchanging view, nor has there even been a practical consensus in the modern era on this issue since 1957, when Northrop Frye published his famous Anatomy of Criticism. ${ }^{46}$ Like most products of culture, the stated purposes behind literary theory have varied according to historical and social conditions. Indeed, as Imre Salusinszky states in the introduction to his book Criticism in Society:

Literary criticism, if it is a discipline, is surely that discipline which has been most exclusively concerned with the question of its own function. The main subject within criticism always seems to have been "The Function of Criticism," and one could construct a brief history of the field simply by tracing the sequence of major essays bearing that title. ${ }^{47}$

For example, as students of the history of criticism have pointed out, the Fathers of modern English literary criticism, Addison and Steele, were

46. N. Frye, Anatomy of Criticism (1957).

47. I. Salusinszky, Criticism in Society 1 (1987). Salusinszky gives as examples essays by Matthew Arnold "The Function of Criticism at the Present Time," in R. H. Super, ed., M. Amold, Lectures and Essays in Criticism (1962); T. S. Elior's "The Function of Criticism at the Present Time," in F. Kermode, ed., Selected Prose of T. S. Eliot (1975); Northrop Frye's "The Function of Criticism at the Present Time," 19 U. Toronto Q. 1 (1949), and Terry Eagleton's The Function of Criticism (1984). 


\section{LAW AND SOCLAL INQUIRY}

quite interested in literature for reasons that Judge Posner would find (to use his favorite expression of distaste in the book) "tendentious." It is no small irony that Posner, a self-proclaimed protector of Enlightenment values, would find himself quite at odds with the function of criticism as understood in the Enlightenment itself:

Literary criticism as a whole, at this point, is not yet an autonomous specialist discourse, even though more technical forms of it exist; it is rather one sector of a general ethical humanism, indissociable from moral, cultural and religious reflection. The Tatler and Spectator are projects of a bourgeois cultural politics whose capacious, blandly homogenizing language is able to encompass art, ethics, religion, philosophy, and everyday life....

The critic as cultural commentator acknowledges no inviolable boundary between one idiom and another, one field of social practice and the next; his role is to ramble or idle among them all, testing each against the norms of that general humanism of which he is the bearer. ${ }^{48}$

What was true of literary criticism during the Enlightenment was also true of literature. As one literary historian has pointed out, ${ }^{49}$ satire was a dominant form of literary expression in the Augustan period precisely because it was a method of commenting on the social and cultural events of the day. For this reason, persons schooled in the New Critical paradigm of literature and literary theory mistakenly believed that the Augustans had no literary theory concerning satire

because [the Augustans'] discussions of the genre consider only its social function and the motives of the satirist. . . [ [However,] the judgment that the Augustans had no theory of the genre at which they excelled is based, of course, on a particular notion of what poetry is. If the poem is thought to be an "organic system of relationships," then it is true that eighteenth century critics have nothing to say in the matter. But if poetry is thought of as a weapon to be hurled against an opponent, as a partisan activity whose purpose is to advance individual and factional interests, then its social function and the motives of its users inevitably occupy the center of critical discussion..$^{50}$

Thus, what is most troubling about Judge Posner's glib pronouncements about the proper function of literature or literary criticism is their

48. T. Eagleton, The Function of Criticism 18-19 (1984). For a similar analysis, see P. Hohendahl, The Institution of Criticism 52-53 (1982).

49. Tompkins, "The Reader in History" (cited in note 16).

50. Id. at 211 (footnotes omitted). 
total innocence of historical context. In this light, Posner's assumption that his vision of criticism is the dominant and therefore appropriate form of literary criticism is doubly problematic-first, because all of the recent developments since Frye have been reactions to and rejections of this vision, and second, because Posner's claims of hegemony are themselves a method of domesticating literature and preventing other methods of literary criticism (which might have more applicability to law) from being accepted in the legal community.

If the purposes for writing those works that we group together as literature have changed over time, and if the "proper function" of literature has changed with each change in literary theory's understanding of its own function, it is perhaps not surprising that the group of texts we call literature can be put to many different uses. ${ }^{51}$ This brings us to the third issue-the different possible uses of literature, as opposed to its intended purpose or assigned function.

Much literature has always has had a didactic use, even if this was not always the reason for its original creation or consistent with the function of literature as understood by any given generation of literary critics. Literature-whether in the form of novels, poems, drama, or oratory-is a very effective tool for communicating ideas. That is why Jesus taught in parables and why ministers still use them today. Storytelling can be an excellent method of criticism, even if it is not your own story. The generality of literature-the very factor that Posner suggests is the reason why literature should not be tied to modern political and social issues (at 15, 356-57) - is precisely the feature that makes it possible for literature to speak to modern concerns. Posner, who waxes eloquent on the importance of rhetoric in persuasion later on in this book, should understand the power of literary examples as well as anyone. Indeed, one suspects that what most disturbs Posner is the possibility that using great works of literature to engage in political and cultural criticism increases the persuasiveness of these criticisms:

[T] he wilder an interpretation, the less authority it can draw from the interpreted work. If Richard Weisberg wants to use Billy Budd as the jumping-off place for his attack on law, that is fine, but he should make clear that it is his attack, not anything to do with Melville. If Kafka reminds Robin West of how much she dislikes capitalism, and thereby stimulates her to critical reflections about it, that is fine too, but she is not entitled to wrap her criticisms in the mantle of Kafka's immense prestige. (At 186, first and last emphases added)

51. A deconstructionist would argue that this does not follow from literature's nature as literature, but simply from its textuality, because a text must be iterable (and capable of serving an indefinite number of functions) in order to function as a text. But one need not be a deconstructionist to accept the less general point that historical experience has demonstrated that what the canon decrees as "literature" can serve many different uses. 
Posner's project of domestication is clearly at work here. The underlying concern is the authority that the text (or the author of a text) gives to an interpretation associated with the text. Although Posner appears to be preserving the authority of the literary text, by protecting it from interpretive distortion, or by preventing it from serving petty political purposes, he is simultaneously limiting the authority of the text, by suppressing its possible political and cultural meanings and forbidding such interpretive use by others.

Nevertheless, when Posner is interested in criticizing Robin West's and Richard Weisberg's politics only a few pages earlier in the book, he has no scruples about giving us his (eccentric, to put it mildly) interpretation of Dostoevsky's "The Grand Inquisitor" from The Brothers Karamazov to make his point. ${ }^{52}$ Of course, West or Weisberg could respond by using "The Grand Inquisitor" to critique the authoritarianism of the Reagan era. ${ }^{53}$ But the fact that both Posner and his critics can and do engage in such "political" interpretations is precisely the point. Whether or not literature is written to instruct or entertain, it has the capacity to bring issues before the mind in a striking way. To use literature to comment upon aspects of modern culture is illegitimate only if one has decided before the fact that literature should not be used other than for the purposes New Criticism decreed for it. And since these purposes and this

52. In comparing West's assessment of human nature to that of the Grand Inquisitor, Posner claims that "[ $t]$ he Grand Inquisitor's argument [that it is sometimes better for people to entrust decision making to others] can be transposed into economic terms-indeed, there is more than a hint of such a transposition in his diatribe" (at 201). If Posner thinks that the reason why he disagrees with the Grand Inquisitor's view of human nature is the same reason Dostoevsky did (to the extent that he did), he has misunderstood Dostoevsky. By the time Dostoevsky wrote The Brothers Karamazov, he was a sworn foe of Western Enlightenment values, which were at that point in history virtually the same as the classical liberalism that Posner believes to be vindicated by his interpretation of "The Grand Inquisitor." To be sure, Dostoevsky's criticisms were aimed not only at liberalism and Catholicism, but also at socialism. Yet it is important to understand that Dostoevsky despised socialism not because he was an economic libertarian convinced of socialism's inefficiencies, but because of socialism's pretensions to improve mankind through reason and science-in other words, he hated socialism for its attempted furtherance of the basic Enlightenment project. He distrusted its utilitarianism, its secularism, and its unswerving faith in science. Doestoevsky's vision of freedom is thus not the freedom of the economic libertarian, rationally calculating what is in her (or in humanity's) best interests. It is a vision of freedom posed against reason and towards unreasoned faith in Christ. See generally K. Mochulsky, Dostoeusky: His Life and Work (M. Minihan trans. 1967). Certainly if Posner is miffed about West wrapping herself in Kafka's mantle, one might be equally miffed at Posner's donning Dostoevsky's dressing gown.

53. One might begin this counterinterpretation by noting that in the Grand Inquisitor's ideal world, people give up their individual freedoms in exchange for the promise of bread (read here material comfort), so that ultimately even the decision whether "to have or not to have children" is made for them by the government. R. Posner, Law and Literature, at 202 (quoting F. Dostoevsky, The Brothers Karamazov 240 (Constance Garnett \& Ralph E. Matlaw trans., Matlaw ed. 1976)). I can see it now: Ronald Reagan as the Grand Inquisitor, Ivan Boesky as Ivan Karamazov . . . well, you get the general picture. 
paradigm are best suited to preserve the political quiescence of literature, ${ }^{54}$ clinging to the New Critical paradigm as the only appropriate paradigm of critical discourse is simply question begging.

\section{CONCLUSION}

Throughout Law and Literature: A Misunderstood Relation, there is a certain tone of condescension about law and literature-the sort of patronizing attitude one reserves for persons whom one sees as still beneath one, and wants to make certain remain there:

[T] he study of law is undergoing fundamental change. ... Today it is widely accepted that the study of law is inescapably interdisciplinary and that unless the academic lawyer borrows the methods and insights of other fields, he will lose his right to dominate legal studies. Recognition of this point has progressed furthest with regard to the use of economics in the study of law, but philosophy is also making great strides.... And now there is this new form of interdisciplinary legal studies, law and literature, making rapid strides though perhaps on short legs. (At 362-63, footnote omitted)

The crucial issue in modern academic law is the "right to dominate legal studies," which, after the collapse of the legal process school, belongs no longer to law itself, according to Posner, but to economics. This explains the condescension towards law and literature-an infant who, still on its short legs, is not yet prepared to challenge economics. Nor would such a challenge be wise, for, as Posner tells us:

I am not suggesting that a course in law and literature should be placed at the center of the law school curriculum. The field lacks the theoretical coherence, convergent thrust, parallelism to legal doctrine, and practical application to lucrative fields of practice that have given the law and economics movement so important a place in the curriculum of leading law schools. Moreover, insofar as immersion in the field of law and literature may impart an excessively detached or skeptical view of legal doctrine, law students may be led to reject legal doctrine before they have learned it (at 361).

This passage, more than any other, typifies the outward bluff and the inward apprehension that constitute this book-the simultaneous condescension towards law and literature and admonishment about its dangerous tendencies. Law and literature is a child who can never be allowed to

54. See T. Eagleton, Literary Criticism, An Introduction 50-51 (1983). 
grow up, a woman who can never be liberated ${ }^{55}$-it must remain peripheral to the law school curriculum, not only because it is not coherent, practical, or connected to lucrative endeavor, but because it might prove too threatening. Law and literature thus empowered might breed skepticism about the authority and justness of current legal doctrine. Hence, Posner concludes that

I hope this book will both promote the cause of interdisciplinary legal studies and encourage fresh thinking about the structure of academic law. But if it merely reawakens a delight in literature in some lawyers, or stimulates some fresh thinking on the eternal problems of law and justice, I shall be content. (At 364)

Indeed, if that were all that law and literature did, Posner would certainly rest content. The best strategy for retaining the "right to dominate legal studies" is to relegate potential opponents to harmless, peripheral situations, all the better to justify their description in condescending terms. Posner has learned well the techniques of the neighborhood bully, who swaggers all the more imperiously so as to avoid serious threats to his dominance. Posner assures us that things will go smoothly in the legal academy as long as everyone knows her place.

In witnessing over and over again the ideological project of this book: the law of necessity by which it must appropriate the literary, place it securely within a gilded cage, assign it to a comfortable but ineffectual sinecure-we have indeed seemed to bring everything back to the opposition between the serious picture and the smiling picture, the separation between the Father and the Mother-the relegation of the Mother to the kitchen and the nursery, if you will, of legal scholarship. But these ideas, this strategy, would have doubtless surfaced in other metaphors even had we never examined these marginal features of the book. For this text, Law and Literature: A Misunderstood Relation, like all texts, is a continuous source of its own problematics, a never ending though unintended commentary on its own ideological presuppositions. This should come as no surprise. Deconstruction in particular, and literary theory in general, could teach lawyers that, if they were inclined to listen.

55. Here one can hardly avoid noticing in Posner's descriptions of economics and law the "male" metaphor of "convergent thrust," to which law and literature is opposed. The recurring association of literature with the stereotypical characteristics of the feminine (and finally, in the above passage, with those of the immature child) is one of the most illuminating and disturbing aspects of this book, which would no doubt provide ample opportunity for a feminist analysis. Such an analysis is beyond the scope of the present article. Suffice it to say that Posner's use of stereotypical male and female metaphors to depict the oppositions of reason and passion, economics and literature, or law and literature, is simply another device by which he attempts to allocate and deny authority. 